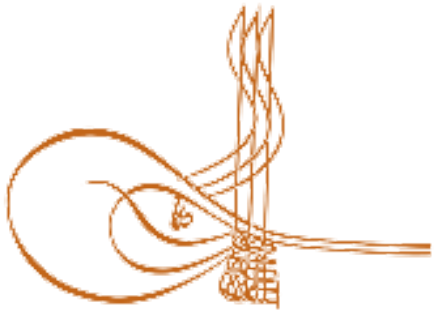

www.turkishstudies.net/education
Turkish Studies - Educational Sciences

eISSN: $2667-5609$

Research Article / Araștırma Makalesi

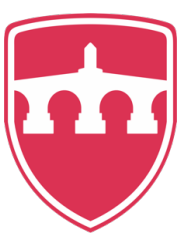

INTERNATIONAL

BALKAN

UNIVERSITY

Sponsored by IBU

\title{
Harmanlanmış Öğretim Ortamında Dyned Kullanılmasına İlişkin Öğrenci Görüşleri
}

\author{
Students' Opinions on Using Dyned in a Blended Teaching Environment
}

\author{
Adem Uzun* - Beyhan Çıtak ${ }^{* *}$
}

\begin{abstract}
The purpose of this study is to investigate students' opinions, students' usage of DynEd and their English academic success regarding the implementation of a computer assisted English language software, DynEd, being used via blended teaching method. A qualitative case study method was applied in the study which consisted of 87 6th-grade students of a public school of the province of Bursa. DynEd's Placement Test was conducted in order to determine English level of the students prior to the study. Following the test, a blended teaching method was applied to the students for three months. Subsequently, DynEd's Placement Test was re-applied to the students and the students' opinions on DynEd were taken with the open-ended questions. Following the study, the students' usage of DynEd was analyzed as a document analysis by using DynEd's Records Manager; their Placement Test results were analyzed descriptively; and the open-ended questions were analyzed using content analysis method. According to the findings obtained from open-ended questions, a significant proportion of the students who expressed their opinions showed a positive attitude (66.2\%) towards DynEd.In general, the students found teacher support important and useful while using DynEd; they found it motivating being given award (45\%) and star shaped sticker (34\%) to those who made most progress in DynEd software. They stated that voice recording and repetition features of DynEd software are useful, while they found the pace of unit progression in the software slow. Furthermore, they expressed that DynEd enhances English speaking, reading and listening skills. On the other hand, they emphasized that the software should be designed more engaging. Among the interaction buttons on Dyned software interface, the students used the repeat button the most, used the microphone and headphone buttons less and similar with each other. The use of the software in this way shows that it is properly and effectively used. According to DynEd user guide; when the students' average duration of DynEd use (7 hours 19 minutes) was taken into consideration, it was determined that DynEd wasn't used sufficiently. In terms of Dyned Placement Test; although the students were more successful in the final test, that success difference was found not to be significant in accordance with DynEd user guide.
\end{abstract}

\footnotetext{
* Doç. Dr., Bursa Uludağ Üniversitesi, Eğitim Fakültesi, Bilgisayar ve Öğretim Teknolojileri Eğitimi Bölümü Assoc. Prof. Dr., Uludag University, Faculty of Education, Computer Education and Instructional Technologies ORCID 0000-0001-6935-346X auzun@uludag.edu.tr ** Bilişim Teknolojileri Öğretmeni, 23 Nisan Ortaokulu

IT Teacher, 23 Nisan Secondary School

ORCID 0000-0001-6347-0470

beyhancitak@gmail.com

Araştırma verileri 2015 yılında toplandığı için çalışmamız etik kurul onayı gerektirmemektedir.

Cite as/ Atıf: Uzun, A. \& Çıtak, B. (2020). Harmanlanmış öğretim ortamında dyned kullanılmasına ilişkin öğrenci görüşleri, Turkish Studies - Education, 15(2), 1299-1318. https://dx.doi.org/10.29228/TurkishStudies.41504

Received/Geliş: 28 January/Ocak 2020

Accepted/Kabul: 27 April/Nisan 2020

Checked by plagiarism software

Copyright (C) INTAC LTD, Turkey

Published/Yayın: 30 April/Nisan 2020

CC BY-NC 4.0
} 
Structured Abstract: Introduction and Purpose: The purpose of this study is to investigate student views, students' use of DynEd and their academic success in English regarding DynEd usage with blended teaching method. In this context, the study seeks answers to the following research questions:

1) What are the student opinions regarding DynEd software being used in a blended teaching environment?

a. What are the positive and negative student opinions regarding the use of DynEd software?

b. Does DynEd software contribute to the development of students' academic English levels?

c. What are the positive and negative opinions of the students about the activities of the teacher in the classroom in the application of blended teaching method?

2) How often did the students use the interaction buttons (repeat, microphone, headset etc.) of the DynEd software in the blended teaching method environment and how much time did they spend in the DynEd software?

3) What are the students' success in DynEd Placement Test in the blended teaching environment?

\section{Method}

In this study, in which 87 students attending 6th grade in a public school in Bursa province participated, a case study, one of the qualitative research methods, was applied.

Prior to the study, DynEd software Placement Test was administered to students to determine their English level. After this test, blended teaching method was applied to the students for three months. Then the Placement Exam was applied again to the students and open-ended questions were asked through the openended questionnaire form, and the opinions of the students about DynEd were taken.

After the study, using the Records Manager of DynEd software, students' status of using DynEd software and Placement Test scores were analyzed descriptively, and open-ended questionnaire questions were analyzed by content analysis method. Prior to the study, open-ended questionnaire questions prepared in the study were presented to the opinions of three specialists and one grammar specialist In line with the opinions received, necessary corrections were made to the questions. In addition, a pilot study was conducted before asking these questions to the students with five 6th grade students. In this application, four open-ended questions were finalized by bringing additional explanations to questions that were not understood by examining students' answers.

\section{Results and Discussion}

Regarding the first research question of the study, it was concluded that the students' views on the use of DynEd software with blended teaching method were generally positive. According to the findings obtained from the open-ended questions, it was seen that most of the students $(66.2 \%)$ have positive attitudes towards DynEd software. This situation coincides with the studies examining the general views on the use of DynEd in the literature (Baş, 2010; Ellsworth, 2015; Inal \& Korkmaz, 2019; Kim et al., 2014; Meri, 2012; Özek \& Pektaş, 2016; Tresnawati, 2011; Ucur, 2010).

Regarding DynEd usage levels in the second research question of the study, it was seen that the average time of using DynEd for the students was 7 hours and 19 minutes. However, according to the DynEd software manual, this period should be 2 hours per week on average and 24 hours in 12 weeks (DynEd International Inc., 2004; 2008; 2013). This reveals that despite all efforts, students were not using DynEd adequately. Additionally, important results were obtained in terms of the opinions of the students in the second research question of the study regarding the ways of using DynEd. First of all, concerning features of the DynEd program, students found DynEd useful in terms of recording their own voices, listening to what they heard, and subtitling and tutor features respectively. In addition, some of the students in the context of negative opinions stated that in the DynEd program, unit progress rate is slow and that the completion rate of the unit does not have to be $80 \%$ to open the DynEd mastery tests. Gobel (2008) and Uras (2018) reported similar demands regarding the software.

When the findings related to the third research question of the study were analyzed, it was observed that, in terms of the placement test, the students achieved an average of 22 points (level of 0.05) on the test 
taken previously, 30 points (level of 0.10 ) on the test taken subsequent to the study. This result is supported by the results obtained from the literature (Bahri, 2016; Bingham \& Larson, 2006; Brown et al., 2008; Huang \& Wu, 2013; Inal \& Korkmaz, 2019; Kagaoan et al., 2012; Kim et al., 2014; Tresnawati, 2011; Uras, 2018). On the other hand, even though the students were more successful after the blended teaching, it was seen that this achievement difference according to the DynEd guide was not at a significant level. According to the DynEd software guide, there should be a significant improvement of the student in the Placement Test and a level increase of at least 0.25 (DynEd International Inc., 2004; 2008; 2013; 2017). It was thought that this is because the students' DynEd usage and test scores don't affect their academic success. Kim et al. (2014), who found similar results, stated that the use and success of DynEd is not very high due to the students' scores that not affecting their general academic succes.

Based on these results of the study, the following suggestions can be made to the Ministry of National Education and English teachers in order to implement DynEd software more effectively and efficiently in public schools in our country:

- A website with information on the effective implementation of DynEd, good examples can be shared and other posts can be established, or a special area for DynEd can be added on www.eba.gov.tr. In this way, by creating an informative platform for all teachers and students, a motivating effect on the use of DynEd can be achieved.

- As an alternative to the Elective English lessons taught in schools, Elective DynEd Lesson can be added. Thus, the blended learning environment proposed by the DynEd system can be created and the highest level of efficiency can be obtained in terms of English education and DynEd usage.

Keywords: Education Technologies, Computer-Assisted Language Learning, Dyned, Blended Learning

Öz: Bu çalışmanın amacı bilgisayar destekli İngilizce öğretim yazılımı olan DynEd'in harmanlanmış öğretim yöntemi ile uygulanmasına ilişkin; öğrenci görüşlerini, öğrencilerin DynEd kullanım durumlarını ve İngilizce akademik başarılarını incelemektir. Çalışma grubunu Bursa ilinde bir devlet okulunda 6. sınıfta okuyan 87 öğrencinin oluşturduğu araştırmada nitel araştırma yöntemlerinden durum çalışması uygulanmıştır. Çalışma öncesinde öğrencilerin İngilizce seviyelerini belirlemek amacıyla DynEd Düzey Belirleme Sınavı yapılmıştır. Sonrasında öğrencilere üç ay boyunca harmanlanmış öğretim yöntemi uygulanmıştır. Ardından Düzey Belirleme Sınavı öğrencilere tekrar uygulanmış ve açık uçlu anket soruları sorularak öğrencilerin DynEd hakkındaki görüşleri alınmıştır. Öğrencilerin DynEd yazılımını kullanma durumları ve Düzey Belirleme Sınav başarıları betimsel olarak, açık uçlu anket soruları ise içerik analizi yöntemi ile incelenmiştir. Açık uçlu anket sorularından elde edilen bulgulara göre görüş bildiren öğrencilerin önemli bir kısmı DynEd'e karşı olumlu bir tutum $(\% 66,2)$ sergilemektedirler. Genel olarak öğrenciler, DynEd kullanımında öğretmen desteğini faydalı ve önemli; DynEd yazılımında en çok ilerleyenlere ödül (\%45) ve yıldız çıkartma (\%34) verilmesini motive edici bulmuşlardır. DynEd yazılımının ses kaydı ve tekrar özelliklerini faydalı; program içindeki ünite ilerleme hızını ise yavaş bulmuşlardır. Bunun yanı sıra DynEd'in İngilizce konuşma, okuma ve dinleme becerilerini arttırdığını ifade etmişlerdir. Öte yandan öğrenciler bu yazılımın daha ilgi çekici tasarlanması gerekliliğini vurgulamışlardır. Öğrenciler DynEd yazılımı arayüzündeki etkileşim butonları içinde en çok tekrar butonunu kullanmışlardır. İkinci sırada ise mikrofon ve kulaklık butonlarını kullanmışlardır. Yazılımın bu şekilde kullanılması onun doğru ve etkili kullanıldığını göstermektedir. Üç aylık eğitim süresi göz önüne alındığında DynEd kullanım kılavuzuna göre, öğrencilerin ortalama DynEd kullanım sürelerinin yeterli olmadığı bir diğer ulaşılan sonuç olmuştur. Düzey Belirleme Sınavı açısından ise öğrenciler, ortalama olarak eğitim sonrası yapılan sınavda öncesinde yapılana göre daha başarılı olsalar da DynEd kılavuzuna göre elde edilen bu başarı farkının yeterli düzeyde olmadığı görülmüştür. Araştırma verileri 2015 yılında toplandığı için çalışmamız etik kurul onayı gerektirmemektedir.

Anahtar Kelimeler: Eğitim Teknolojileri, Bilgisayar Destekli Dil Öğretimi, DynEd, Harmanlanmış Öğretim Yöntemi 


\section{Giriş}

Teknoloji, kaydettiği ilerlemeyle birlikte özellikle kolaylaştırıcı etkisiyle hayatımızın her alanında kendini göstermektedir. Özellikle 1980'lerde kişisel bilgisayarların yaygınlaşması bilgisayarların eğitim alanında da kullanılmasına yol açmıştır. Sonrasında bilgisayar teknolojisi yabancı dil öğretiminde de kendine yer bulmuş ve böylece Bilgisayar Destekli Dil Öğretimi (BDDÖ) ortaya çıkmıştır.

'Dynamic Education (dinamik eğitim)' kelimelerinin kısaltması olan DynEd; dünyanın çeşitli ülkelerinde kullanılan, okul öncesi eğitimden yükseköğretime kadar çeşitli eğitim yazılımlarından oluşan bilgisayar destekli gelişmiş bir İngilizce dil eğitim sistemidir. Bu sistemde DynEd; bilgisayar destekli İngilizce eğitim yazılımları ile sınıf içinde yüz yüze eğitimi birleştiren harmanlanmış öğretim ortamı sağlamaktadır. Bu bağlamda DynEd'in sunduğu harmanlanmış öğretim ortamında BDDÖ yazılımı ile öğrenci; dilin yapısını, kurallarını, kelime ve diğer bilgileri öğrenir ve çeşitli etkinlikleri yapma imkânı bulur. Diğer yandan öğrendiği bu bilgileri sınıf içi etkinlikler sayesinde, öğretmen rehberliğinde akranları ile iletişime geçerek sosyal bir ortamda kullanma ve kişiselleştirme firsatı yakalar (Knowles, 2004).

Ülkemizde 2008-2009 eğitim-öğretim y1lından itibaren DynEd'in "First English" ve "English for Success" eğitim yazılımlarının Millı̂ Eğitim Bakanlığına (MEB) bağlı okullarda kullanılmasına başlanmıştır. MEB DynEd'in haftada en az bir ders saati BT laboratuvarlarında İngilizce öğretmenleri tarafından öğrencilere kullandırılması ve öğrencilerin yazılımda ilerleme kaydetmeleri gerektiğini yönünde bildirimde bulunmuştur (Baş, 2010). Fakat yapılan araştırmalar, 2014-2015 eğitim-öğretim yılına kadar DynEd yazılımı içerisinde öğretmen eğitimi modülü olmaması ve bu konuda yeteri kadar etkili hizmet içi eğitim verilememesinden dolayı, öğretmenlerin DynEd'in nasıl kullanılması gerektiğine dair yeteri kadar bilgilerinin olmadığı tespit edilmiştir (Baş, 2010; Döngel, 2011; Özgan \& Yiğit, 2011; Sarıcaoğlu, 2010; Şengel, Öncü \& Göktalay, 2012; Yiğit, 2010).

Öte yandan alanyazında yapılan diğer çalışmalara göre öğretmen ve öğrencilerin genel olarak DynEd ile ilgili olumlu tutum sergilemedikleri ve öğrencilerin DynEd'e karşı motivasyonlarının çabuk düşerek DynEd'i çok fazla kullanmadıkları sonucuna ulaşılmıştır (Baş, 2010; Berkant \& Derer, 2016; Coşkun, 2013; Döngel, 2011; Sarıcaoğlu, 2010; Şengel vd., 2011; 2012; 2014). DynEd geliştiricilerinin belirttikleri gibi yazılım ülkemizde sadece bir BDDÖ aracı olarak kullanılmasından dolayı motivasyon düşmekte, istenilen kullanım ve verim sağlanamamaktadır (Baş, 2010; Berkant \& Derer, 2016; Coşkun, 2013; Çakmak, 2012; Döngel, 2011; DynEd International, Inc., 2004; 2009; Knowles, 2004; Meri, 2012; Sarıcaoğlu, 2010). Bahsedilen sorunun çözümü için bu çalışmada DynEd'in harmanlanmış öğretim desteği ile kullanılmasına ilişkin 6. sınıf öğrencilerinin; görüşleri, DynEd kullanım durumları ve İngilizce akademik başarılarının araştırılması hedeflenmektedir.

Alanyazında DynEd ile ilgili görüşlerin araştırıldığı birçok çalışma yapılmıştır. $\mathrm{Bu}$ çalışmalarda genel olarak öğrencilerin DynEd'den memnun oldukları belirlenmiştir (Baş \& Kuzucu, 2009; Baz, 2010; Ellsworth, 2015; Huang \& Wu, 2013; İnal \& Korkmaz, 2019; Kim, Cho \& Lee, 2014; Meri, 2012; Özek \& Pektaş, (2016); Tresnawati, 2011; Ucur, 2010). Baz ve Tekdal'ın 2014'te yaptıkları çalışmaya göre ise öğrenciler DynEd ile ilgili kararsız bir yapı sergilemişlerdir. Bununla birlikte öğrenciler DynEd uygulamasında öğretmenin rolünü önemli görmüşlerdir (Ellsworth, 2015; Huang \& Wu, 2013; Kagaoan vd., 2012; Meri, 2012). Ayrıca öğrenciler tarafindan DynEd'in İngilizcedeki 4 temel dil becerisinden en çok konuşma, bununla bağlantılı olarak telaffuz ve dinleme alanında ilerleme kaydetmede etkili olduğu belirtilmiştir (Bingham \& Larson, 2006; Brown ve diğerleri, 2008; Ellsworth, 2015; Huang \& Wu, 2013). Bunun yanında yapmış olduğu çalışmada Meri (2012); DynEd'in öğrencilerin kendi kendilerine öğrenme olan özerklik kazandırması açısından da etkili olduğunu ortaya çıkarmıştır. 
Öğretmenlerin DynEd ile ilgili görüşleri bağlamında; Baş (2010), Özgan ve Yiğit (2011), Baz (2010) ve Yiğit $(2010 ; 2012)$ çalışmalarında öğretmenlerin öğrencilerin DynEd'e karşı olumlu bakış açısı içinde olduklarını belirtmişlerdir. Brown ve diğerleri (2008), Özgan ve Yiğit (2011), Gobel (2008), Ellsworth (2015)'e göre ise öğretmenler; öğrencilerin DynEd'den yüz yüze yapılan sınıf içi etkinlikleri sayesinde memnun olduklarını ve öğretmenin DynEd kullanımında önemli rol oynadığını belirtmişlerdir.

Öğrencilerin DynEd kullanımı üzerine yurt dışında yapılan çalışmalarda, DynEd'in kullanım kılavuzunda belirtildiği gibi alt yazının az kullanılıp tekrarın daha fazla kullanılması halinde başarının arttığı tespit edilmiştir (Hegelheimer \& Tower, 2004; Tower, 2000). Öğrenciler DynEd kullanımının gözlemlendiği çalışmalarda ise çoğunlukla öğrencilerin DynEd'i etkin kullandıkları tespit edilmiştir (Ellsworth, 2015; Gobel, 2008). Ülkemizde yapılan çalışmalarda ise öğrencilerin DynEd'i genel olarak pek kullanmadıklarını vurgulayan çalışmalar da bulunmaktadır (Berkant \& Derer, 2016; Coşkun, 2013; Şengel vd., 2011; 2014).

Yurt dışında tek bir gruba ön test - son test şeklinde yapılan çalışmalarda DynEd eğitim sisteminin kendi içerisinde sunduğu harmanlanmış öğretim yöntemi ile kullanıldığı durumlarda öğrencilerin İngilizce başarısının anlamlı bir şekilde arttı̆̆ görülmüştür (Bahri, 2016; Bingham \& Larson, 2006; Decena, Basilisco \& Juanillo, 2015; Huang \& Wu, 2013; Kagaoan vd., 2012; Kim vd., 2014). Ülkemizde yapılan tek gruplu çalışmalarda ise İngilizce başarısının artmadığ 1 görülmüsstür (Şengel vd.; 2014).

Öğretmenlerin geneli DynEd'in özellikle öğrencilerin dinleme, konuşma, telaffuz, okuma becerilerini geliştirdiğini, en az ise yazma becerilerini geliştirdiğini dile getirmişlerdir (Çakmak, 2012; Ellsworth, 2015; Sarıcaoğlu, 2010; Yiğit, 2010; 2012). Baz ve Tekdal (2014) ve Çakmak (2012) öğretmenlerin DynEd'i kısmen yeterli görüp DynEd kullanımına kısmen olumlu bakarken; Berkant ve Derer (2016), Coşkun (2013), Yiğit (2010; 2012) öğretmenlerin DynEd'e karşı olumsuz görüş bildirdiklerini ve DynEd kullanmak zorunda oldukları için memnun olmadıklarını belirlemişlerdir. Öte yandan Şengel ve diğerleri (2012) ve Baş (2010) öğretmenlerin DynEd'den memnun olduğunu, Sarıcaoğlu (2010) ise öğretmenlerin mesleğinde tecrübesi arttıkça DynEd'den memnuniyet düzeylerinin de arttığını tespit etmiştir. Ayrıca öğretmenlerin birçoğu DynEd yazılımını kullanmada donanımsal ve teknik sorunlarla karşılaştıklarını belirtmişlerdir (Baş, 2010; Coşkun, 2013; Çakmak, 2012; Ellsworth, 2015; Meri, 2012; Sarıcaoğlu, 2010; Şengel vd., 2012; Yiğit, 2010).

Alanyazında görüldüğü gibi DynEd ile ilgili görüş bağlamında birçok çalışma yapılmıştır. Fakat ülkemizde DynEd'in harmanlanmış öğretim yöntemi ile kullanılmasına ilişkin öğrenci görüşlerini, öğrencilerin DynEd kullanım miktarları ve İngilizce başarılarını inceleyen araştırmalara çok ender rastlanmaktadır. Bu eksikliği gidermek ve alanyazına katkı sağlamak amacıyla bu çalışmada aşağıdaki araştırma sorularına yanıt aranmaktadır:

1) DynEd yazılımının harmanlanmış öğretim yöntemi ortamında kullanılmasına ilişkin öğrenci görüşleri nelerdir?

a. DynEd yazılımının kullanımına ait olumlu ve olumsuz öğrenci görüşleri nelerdir?

b. DynEd yazılımı, öğrencilerin akademik olarak İngilizce düzeylerinin gelişimine katkı sağlamakta mıdır?

c. Harmanlanmış öğretim yönteminin uygulanmasında öğretmenin sınıf içinde yaptığ etkinlikler ile ilgili öğrencilerin olumlu ve olumsuz görüşleri nelerdir?

2) Harmanlanmış öğretim yöntemi ortamında öğrenciler; DynEd yazılımının etkileşim butonlarını (tekrar, mikrofon, kulaklık vb.) ne sıklıkla kulanmışlar ve DynEd yazılımında ne kadar süre geçirmişlerdir? 
3) Harmanlanmış öğretim yöntemi ortamında öğrencilerin DynEd Düzey Belirleme Sınav başarıları nasıldır?

\section{Yöntem}

\subsection{Araștırma Modeli}

Araştırmada nitel araştırma yöntemlerinden durum çalışması kullanılmıştır. "Durum çalışmaları; bir ya da daha fazla olayın, ortamın, programın, sosyal grubun ya da diğer birbirine bağlı sistemlerin derinlemesine incelendiği yöntem olarak tanımlanmaktadır" (Büyüköztürk, Çakmak, Akgün, Karadeniz, \& Demirel, 2016 s. 260 s. 465). Elde edilen nitel veriler içerik analizi yöntemi ile incelenmiş̧ir. İçerik analizi, belirli kurallara dayalı kodlamalarla bir metnin (ya da anlamlı diğer içeriklerin) bazı sözcüklerinin daha küçük içerik kategorileri ile özetlendiği sistematik, yinelenebilir bir araştırma tekniğidir (Büyüköztürk vd., 2016; Krippendorff, 2004). DynEd yazılımına ait 'Kayıt Yöneticisi' kullanılarak elde edilen veriler için ise doküman incelemesi yapılmış ve veriler betimsel istatistiklerden yararlanılarak incelenmiştir.

\section{2 Çalışma Grubu}

Araştırmanın çalışma grubu Bursa ili Osmangazi ilçesinde bir devlet okulundaki 6. sınıf öğrencilerinden dört şubeden oluşmaktadır $(n=87)$. Çalışma grubunun seçiminde kolay ulaşılabilir örneklem yöntemi kullanılmıştır. Çalışma grubu öğrencilerinden 47'si erkek (\%54), 40'1 ise kızdır (\%46). Araştırma 2014-2015 eğitim öğretim yılının ikinci döneminde gerçekleştirilmiştir.

\subsection{Veri Toplama Araçları}

\subsubsection{Açık Uçlu Anket Formu}

Açık uçlu anket formu ile sorulan sorular birinci araştırma sorusu ile ilgili verileri toplamada kullanılmıştır. Bu sorular ile DynEd eğitim yazılımı ve uygulanan harmanlanmış öğretim yöntemi ile ilgili öğrencilerin düşünce ve görüşleri belirlenmeye çalışılmıştır

Öğrencilere sorulan açık uçlu anket maddeleri şunlardır:

1) DynEd yazılımının kullanımını ve özelliklerini değerlendiriniz. Açılayınız.

2) DynEd yazılımı; akademik olarak İngilizce başarınıza hangi yönlerden katkı sağladı?

3) DynEd yazılımının etkin kullanılması ile ilgili öğretmeninizin sınıf içinde yaptığ rehberlik faaliyetlerini değerlendiriniz.

4) DynEd yazılımının etkin kullanılması ile ilgili öğretmeniniz tarafından yapılan motive edici etkinlikleri değerlendiriniz.

\subsubsection{DynEd Kullanım Bilgileri}

Araştırmada öğrencilerin DynEd yazılımına ait First English yazılımını kullanmaları istenmiştir. First English, kullanıcıların İngilizce seviyesini başlangıç düzeyinden orta-öncesi düzeyine taşıyan, 10-17 yaş arası öğrenciler için tasarlanmış çoklu ortam yazılımıdır. Bu yazılımı kullanırken öğrenciler yazılım arayüzünde bulunan etkileşim butonlarını kullanmaları gerekmektedir. Şekil 1'de First English yazılımı arayüzündeki önemli etkileşim butonları tanitilmaktadir. 


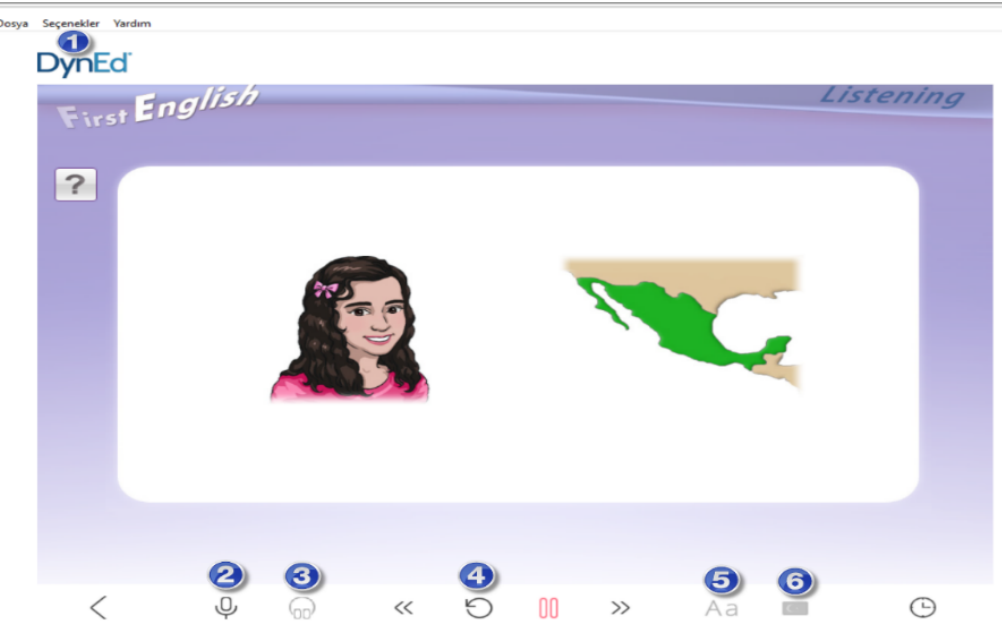

Şekil 1: DynEd First English Yazılımı Arayüzü

Şekil üzerindeki 1 numarada Seçenekler-Terimler Sözlüğü ile ünite içerisinde geçen önemli kelimelerin anlamları verilmektedir. 2 numaradaki mikrofon simgesi ile ses kaydı yapılır; 3'teki kulaklık simgesine tıklayarak kaydedilen ses dinlenir; 4'teki simge ile program içerisinde ana dili İngilizce olan kişilerin konuştukları tüm cümle, kelimeler vb. tekrar ettirilir; 5'teki Aa simgesi ile konuşmalara ait İngilizce alt yazı ve 6'daki Türk bayrağ 1 simgesi ile ise konuşulan cümlelere ait Türkçe alt yazı görüntülenir.

Veri toplama aracı olarak DynEd kullanım bilgilerini ortaya çıkartmadaki amaç öğrencilerin DynEd yazılımını kullanırken tekrar, çeviri, mikrofon gibi etkileşim butonlarını ne sıklıkla kullandıklarını ve DynEd'de ne kadar süre geçirdiklerini ölçmektir. Bu bilgileri ortaya çıkarmak için DynEd yazılımının Kayıt Yöneticisi aracına başvurulmuştur. Kayıt Yöneticisi; DynEd yazılımının kurulması ile birlikte gelen sadece öğretmen ve yöneticilerin kullanıcı adı ve şifreleri ile girebildikleri bir yazılım modülüdür. Bu modül, öğretmen ve yöneticilerin öğrenci ve sınıf kayıtlarını yönettikleri ve tuttukları araçtır (DynEd International Inc., 2008).

DynEd kullanım bilgileri ikinci araştırma sorusu ile ilgili verileri elde etmede kullanılmıştır. Şekil 2'de numaralarla gösterilen bilgiler araştırmada öğrencilerin DynEd yazılımı kullanım bilgileridir.

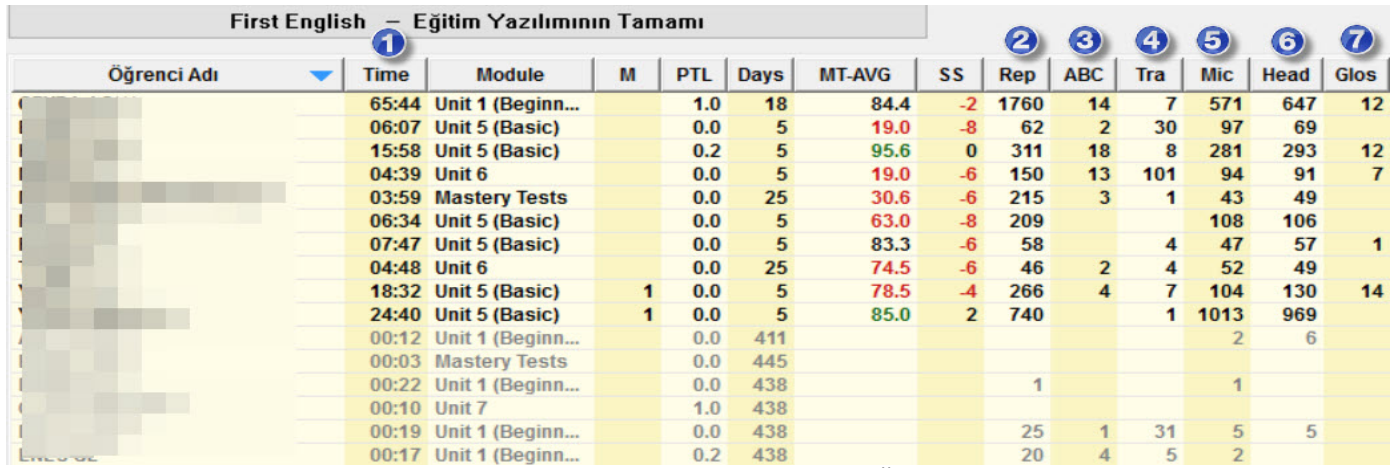

Şekil 2: Kayıt Yöneticisi Ekran Örneği

Şekil 2'nin üzerindeki numara sırasına göre öğrencilerin DynEd kullanımına ait toplam süre ve sayılar şu şekildedir: 
1. Süre (Time): DynEd'i kullanırken geçirilen toplam süre. (Çalışmada sadece süre sadece dakika cinsinden alınmıştır. Şekilde ise saat: dakika cinsinden gösterilmektedir.)

2. Tekrar (Rep): Tekrar butonunun kullanılma sayısı. Bu buton ile yazılımda duyulan cümle, kelime, harf gibi sesler tekrar dinlenir.

3. ABC: İngilizce alt yazı gösterim sayısı.

4. Çeviri (Tra): Türkçe alt yazı gösterim sayısı.

5. Mikrofon (Mic): Ses kaydetmek için mikrofon kullanım sayısı.

6. Kulaklık (Head): Kaydedilen sesi dinleme sayısı.

7. Sözlük (Glos): Sözlük kullanım sayısı.

\subsubsection{Düzey Belirleme Sinavı}

Düzey Belirleme Sınavı, DynEd'in uygun ders yazılımı ve ünitesinden başlaması için öğrencinin düzeyinin belirlenmesini sağlar. Aynı zamanda bu sınav öğrencinin genel dil becerisini ölçer. Araştırmada öğrencilerin akademik olarak İngilizce seviyelerini belirlemek için kullanılan düzey belirleme sınavı, üçüncü araştırma sorusu ile ilgili veri elde etmede kullanılmıştır. Sınavın öğrencilerin kullanıma açılması ve sınavla ilgili detaylı sonuçlar ve diğer tüm işlemler Kayıt Yöneticisi kullanılarak yapılır. Dyned Düzey Belirleme Sınav1; dinleme, anlama, dilbilgisi ve kelime bilgisi odaklı; genel olarak cümle seviyesinde anlamayı ölçen bilgisayar uyarlamalı bir sınavdır (DynEd International Inc. , 2013). DynEd'in bilgisayar uyarlamalı Düzey Belirleme Sınavında, soru sayıs1 ve soru zorluğu öğrencinin performansına göre değişir. Öğrenci sorulara doğru cevap verdikçe seviye artarak daha zor sorular gelir. Seviyesi düşük öğrencilerde ise soru zorluğu artmaz ve daha az sürede sınav biter. Sınav sonunda öğrenci puan ve düzey olarak iki farklı açıdan sonuç elde eder. Aşağıdaki Tablo 1, Teacher's Guide for DynEd's Placement Tests'den (2013) uyarlanmış olup toplam alınabilecek puan ve düzey bağlamında detaylı bilgi vermektedir.

Tablo 1: Dynet Düzey Belirleme Sinavı Seviye Tablosu

\begin{tabular}{ccc}
\hline Puan & Düzey & Uygun DynEd Yazılım ve Kursları \\
\hline $0 \sim 31$ & 0,0 Başlangıç & First English Ünite 1 \\
$32 \sim 71$ & 0,2 & First English Ünite $2 \sim 3$ \\
$72 \sim 111$ & 0,5 & First English Ünite 4 5 \\
$112 \sim 180$ & 0,7 & First English Ünite $6 \sim 7$ \\
$181 \sim 227$ & 1,0 & First English Ünite 8 \\
$228 \sim 250$ & 1,2 veya daha & Düzey Belirleme Sınavi, Bölüm 2 \\
\hline
\end{tabular}

Tablo 1'e göre sinavda öğrenci; 0 ile 250 arasında puan, düzey olarak ise 0 ile 1,2 arasında alabilir. Puan olarak 227'den fazla aldığı zaman sınava ait Bölüm 2 açılır. Örnek olarak sınavdan 100 puan alan bir öğrencinin düzeyi 0,5’tir. Bu duruma göre öğrenci aldığı puana göre, First English yazılımı ünite 4 ya da 5 'ten çalışmaya başlayabilir.

\subsubsection{Güvenirlik}

Güvenirlik bağlamında çalışmada geliştirilen açık uçlu anket soruları; üç alan uzmanı ve bir dilbilgisi uzmanının görüşlerine sunulmuştur. Alan uzmanları öğretim teknolojileri alanından ikisi 10 yıllık, biri ise 12 yıllık deneyime sahip akademisyenlerdir. Üç akademisyenin de DynEd ile ilgili akademik çalışmaları bulunmaktadır. Dilbilgisi uzmanı ise Milli Eğitimde 10 yıllık çalışma deneyimine sahip bir Türkçe öğretmenidir. Gelen görüşler doğrultusunda sorularda gerekli düzeltmeler yapılmış ve pilot uygulama niteliğinde 5 tane 6 . sınıf öğrencisine açık uçlu sorular 
sorulmuştur. Elde edilen cevaplar kontrol edilerek açik uçlu sorulara son hali verilmiştir. Araştırmacının yapmış olduğu kodlamayla ilgili elde ettiği verilerin iç güvenirliğini arttırmak için öğrencilerin açık uçlu anket sorularına verdikleri yanıtlar bir yardımcı araştırmacıya daha gönderilmiştir. Araştırmacı ve yardımcı araştırmacının öğrenci görüşlerine ait yaptıkları kodlamalara ait araştırmanın güvenirliğini belirlemek için Cohen'in Kappa testi yapılmıştır. Bu testlere göre tüm ana temalara ait elde edilen sonuçlar 0,80 'ün üzerinde çıkmıştır (Dört ana tema için $0,89,0,95,0,88$ ve 0,89 )

\subsection{Verilerin Toplanması}

Öncelikle dört şubeden oluşan çalışma grubu öğrencilerine DynEd'in temel yapısı ve Düzey Belirleme Sınavı tanıtılmış ve ardından okul Bilgisayar Laboratuvarında Düzey Belirleme Sınavı uygulanmıştır. Tüm bu işlemler her sınıf için 4 ders saatinde tamamlanmıştır. Ardından 3 ay boyunca öğrenciler, DynEd yazılımını harmanlanmış öğretim yöntemi ile kullanmışlardır. Kullanılan bu yöntemde öğrenciler DynEd'in "First English" eğitim yazılımını evlerinde kullanırken okulda ise her hafta 15-20 dakika süresince öğretmenlerinin rehberliğinde DynEd'in sunduğu sınıf için etkinlikleri yapmışlar ve öğretmenleri tarafından sunulan destek ile motive edilmişlerdir. DynEd yazılımında Kayı Yöneticisinden ulaşılabilen sınıf içi etkinlikler (extension activities) modülü; öğretmen kılavuz kitabı ve İngilizce derslerinde kullanılan öğrenci alıştırma kitabı (workbook) niteliğindedir. Uygulanan sınıf içi etkinliklerinde öğrenciler, karşılıklı diyalog etkinliklerini yapmışlardır. Motivasyon etkinliklerinde ise: a) Öğrencilerin haftalık olarak yazılımdaki ilerlemeleri kontrol edilerek yazılımda etkili ve doğru bir şekilde ilerleyenler motive edilmiş; yazılımın kullanılmasındaki hatalar düzeltilmiştir; b) Haftalık olarak her sınıfta DynEd'de yüzdelik olarak en çok ilerleyen ilk 3 öğrenciye yıldız çıkartma verilmiş; c) Aylık olarak en çok ilerleyen 3 öğrencinin adı ve resimleri okulun sunum amaçlı kullanılan TV ekranında video şeklinde yayınlanmış: d) Bursa İl Milli Eğitim Müdürlüğü tarafından ortaokul seviyesinde ikinci dönem sonunda DynEd'de en çok ilerleyen ve başarılı olan öğrencilerden birincisine ödül olarak tablet bilgisayar hediyesi verileceği haberi öğrencilere duyurulmuştur. Eğitim sürecinin ardından ilk başta kullanılan Düzey Belirleme sınavı öğrencilere tekrar uygulanmış ve ardından açık uçlu anket öğrencilere uygulanmıştır.

\subsection{Verilerin Analizi}

Birinci araştırma sorusu ile öğrencilerin DynEd hakkındaki görüşlerinin alındığı açık uçlu sorulara verdikleri cevaplar içerik analizi ile incelenmiştir. Nitel araştırma verileri içerik analizi yöntemi ile dört aşamada analiz edilir: "(1) verilerin kodlanması, (2) temaların bulunması, (3) kodların ve temaların düzenlenmesi, (4) bulguların tanımlanması ve yorumlanması" (Yıldırım \& Şimşek, 2011, s. 228). Bu bilgi ışığında öğrencilerin verdikleri cevaplar cümle içinde geçen anlamlı kelime gruplarından yola çıkarak kodlanmıştır. Ardından birkaç defa daha okuma yapılarak açık uçlu sorular ve öğrencilerin verdikleri cevaplar çerçevesinde 17 adet alt tema ve 5 adet ana tema oluşturulmuş olup kodlar bu temalar altında kategorize edilmiştir. Ardından araştırmacı verilen cevapları tekrar okuyarak ilgili temaya kodlamasını öğrencinin olumlu ifade içeren görüşleri için "2", kararsız ifade içeren görüşleri için "1", olumsuz verdiği yorumları ise " 0 ” yazarak yapmıştır.

İkinci ve üçüncü araştırma soruları için DynEd yazılımına ait Kayıt Yöneticisi kullanılarak doküman incelemesi yapılmıştır. Elde edilen verilerin ise betimsel istatistikleri incelenmiştir.

\section{Bulgular}

Bu bölümde çalışmaya ait elde edilen bulgular her araştırma sorusuna ait bir alt başlık olarak sunulmuştur. 


\subsection{DynEd Yazılımının Harmanlanmış Öğretim Yöntemi Ortamında Kullanılmasına İlişkin Öğrenci Görüşleri}

$\mathrm{Bu}$ araştırma sorusuna öğrencilerin verdikleri açık uçlu yanıtların incelenmesi sonucu; beş adet ana tema çerçevesinde elde edilen bulgular ve örnek öğrenci yanıtlarından kesitler aşağıda sunulmuştur. Yanıtların kime ait olduğunu belirtmede kullanılan isimler takma olup gerçeği yansitmamaktadirlar.

\subsubsection{Programın Özellikleri}

$\mathrm{Bu}$ tema öğrencilerin DynEd programının özellikleri ile ilgili görüşlerinin yer aldığı ana temadır. Tablo 2'de DynEd programının özellikleri ana temasına ait öğrenci görüşlerinin analizi sol tarafta bulunan alt temalar çerçevesinde detaylı olarak verilmektedir.

Tablo 2: Programın Özellikleri Ana Temasına Ait Öğrenci Görüşleri

\begin{tabular}{cccc}
\hline & Olumlu Öğrenci Görüşü & Kararsız Öğrenci Görüşü & Olumsuz Öğrenci Görüşü \\
\hline Tekrar & 26 & 1 & 0 \\
Ses Kaydı & 34 & 1 & 1 \\
Alt Yazı & 11 & 0 & 2 \\
İlerleme Hızı & 0 & 0 & 16 \\
Ek Özellik İsteği & 4 & 0 & 19 \\
Sanal Öğretmen & 10 & 0 & 4 \\
Programın Kurulumu & 36 & 6 & 16 \\
Diğer & 5 & 0 & 1 \\
\hline
\end{tabular}

Tablo 2'ye göre DynEd yazılımında duyulan sesi (cümle, kelime vb.) tekrar dinlemenin faydalı olduğu ile ilgili olumlu görüş belirten öğrenci sayısı 26 iken sadece 1 öğrenci bu konuda kararsız görüş bildirmiştir. Öğrencilerden 34'ü DynEd'de ses kaydı yapmanın faydalı bir özellik olduğunu belirtirken; yazılımdaki alt yazı özelliğini 11 öğrenci faydalı bulmuş ve bu konuda 2 öğrenci olumsuz görüşte bulunmuştur. Öğrencilerden 16's1 DynEd yazılımı içindeki ünitelerin ilerleme hızının yavaş olduğunu ifade etmiştir. 19'u DynEd yazılımını yeterli bulmayıp ek özellik isteğinde bulunmuştur. Sanal öğretmen DynEd yazılımı içerisinde öğrencinin çalışma verimi hakkında bilgiler verip tavsiyelerde bulunan bir özelliktir. Bu özellik ile ilgili 10 öğrenci olumlu görüş bildirirken 4 öğrenci ise olumsuz görüşte bulunmuştur. Programın tabloda yer almayan diğer özellikleri ile ilgili 5 öğrenci olumlu görüşte bulunmuştur.

Programın özellikleri ana teması ile ilgili faydalı olan özellikler açısından öğrenciler; en çok 34 olumlu görüş ile ses kaydını faydalı bulmuşlardır. Ses kaydından sonra olumlu görüss bildirilen özellikler sırasıyla; tekrar 26, alt yazı 11, sanal öğretmen 10 ve diğer 5 şeklinde olmuştur. Öğrenciler en çok 19 tane olumsuz görüş ile programa ek özellik isteğinde bulunarak yazılımı yetersiz bulmuşlardır. Ek özelik isteğinden sonra en çok olumsuz görüş 16 öğrenci ile DynEd ilerleme hızının yavaş olduğu ile ilgili olmuştur. Daha az sayıda 4 öğrenci ile sanal öğretmen ve 2 öğrenci ile alt yazı özellikleri ilgili olumsuz görüşler bildirilmiştir. DynEd programının bilgisayara kurulumunu 36 öğrenci kolay bulurken 16 öğrenci zor bulmuş ve bu konuda 6 öğrenci ise kararsız kalmıştır.

Bu tema ile ilgili görüş bildiren öğrenci yanıtlarından öne çıkanlar şu şekildedir: Duygu, "DynEd içerisindeki ünite ilerleme hızı bence yavaş. DynEd'deki tekrar butonunu kullanmak, ses kaydı yapmak, alt yazı kullanmak çok faydalı. DynEd'de ilerleme hızını görmen, sanal öğretmenin not vermesi, olumlu olumsuz durumları söylemesi beni iyi etkiledi." demiştir. Emir ise "Ses kaydı yapmak, tekrar butonunu kullanmak, alt yazı kullanmak benim Ingilizcemi gerçekten çok güzel bir şekilde etkiledi. Ünitelerin ilerleme hizı gerçekten çok yavaş oluyor. Her üniteyi tamamen tamamlamak bence çok gerekli değil." şeklindeki ifadelerle programla ilgili olumlu ve olumsuz 
düşüncelerini belirtmiştir. Öte yandan Ahmet, "Sanal ögretmeninin desteği bana özgüven verdi. Tekrar ve mikrofon kaydı daha da etkili oluyor." şeklinde olumlu görüş belirtmektedir.

İsmail, "Fazla altyazı kullanmadım. Çünkü Türkçeyi bebek iken yazarak öğrenmedim dinleyerek ve konuşarak. Ama geçekten mikrofon kullanmak çok iyi ögrenmeyi sağllyor. Programın arayüzü basit DynEd'in yaratıcıları basite kaçmışlar. Bence biraz daha neşeli nasıl anlatsam. Yani daha çekici olmalıymış." diyerek alt yazının çok kullanılmaması gerektiği, mikrofon kullanmanın önemini vurgulamakta; DynEd'in ara yüzünün ise daha ilgi çekici yapılabileceği ile ilgili ek özelik isteğinde bulunmaktadır. Gülşen de "Notlarımızı anında ögrrenmemiz iyi bir şey. Yüzde 80 gelmek o kadar gerekli değil bence çünkü bazen bildiğim şeyler çıklyor o yüzden sıkllyyorum bu nedenle iyi bilen herkese mastery test açılmalı." diyerek DynEd'de çok fazla ilerlemenin gerekli olmadığını ve ünitelere ait sınavların üniteleri çalışmadan da açılabilmesi gerektiğini söyleyerek programa ait ek özellik isteğinde bulunmaktadır.

\subsection{2 İngilizceye Katkı}

$\mathrm{Bu}$ tema DynEd yazılımının öğrencilerin akademik olarak İngilizcesini geliştirmede sağladığı katkılarla ilgili görüşlerini inceleyen ana temadır. Bu ana temaya ait 5 adet alt tema bulunmaktadır. Tablo 3'te DynEd'in İngilizceye katkısı ana temasına ait öğrenci görüşleri alt temalar çerçevesinde betimlenmektedir

Tablo 3: İngilizceye Katkı Ana Temasına Ait Öğrenci Görüşleri

\begin{tabular}{ccc}
\hline & Olumlu Öğrenci Görüşü & Olumsuz Öğrenci Görüşü \\
\hline Konuşma & 21 & 0 \\
Dinleme & 11 & 0 \\
Okuma & 16 & 0 \\
Yazma & 9 & 0 \\
Diğer & 29 & 1 \\
\hline
\end{tabular}

Tablo 3'e göre DynEd yazılımının İngilizce öğrenmede sağladığ katkı ile ilgili en çok 29 öğrenci ile diğer teması olumlu görüş almıştır. İngilizceye katkı bağlamında diğer özellikler temasına giren öğrencilerin söylediklerine örnekler: İngilizce derslerine katkı, kelime öğrenme, İngilizceyi geliştirme vb. şeklinde verilebilir. Diğer temasından sonra sırasıyla en çok 21 öğrenci İngilizce konuşma açısından DynEd'in olumlu katkı sağladığını, 16 öğrenci İngilizce okuma becerilerini, 11 öğrenci İngilizce dinleme becerilerini ve en son sırada 9 öğrenci ise DynEd'in İngilizce yazma becerilerini geliştirdiğini belirtmiştir.

$\mathrm{Bu}$ tema ile ilgili görüş bildiren öğrenci yanıtlarından öne çıkanlar şu şekildedir: Duygu, "İnilizce konuşma, dinleme, okuma beni iyi etkiledi dinlemem daha çok gelişti." demiştir. Gülşen ise "Ses kayd yapmak beni telaffuzumu daha iyi oldu anlama becerilerim gelişti. Ben DynEd başladığımdan beri dinleme becerim arttı duyduklarımı daha iyi anlayabiliyorum. Sürekli tekrar yapabiliyor olmamız bizi daha iyi anlayım daha iyi konuşmamızı sağladı." şeklinde İngilizce konuşma, telaffuz ve dinleme becerilerinin geliştiğini ifade etmiştir. Ahmet, "Harflerin ve kelimelerin okunuşunu daha iyi öğrendim." demiş; Fahri, "Önceden de kendim okumam ve yazmam çoğu kelimede doğruydu ancak şimdi konuşmayı da daha net öğrendim. Telaffuzum güzelleşti." ve İsmail de "Bence okuma açısından en çok ilerledim. Çünkü geçen seneye göre iyi telaffuz ediyorum bu değişimimi çok sevdim." diyerek DynEd yazılımı sayesinde İngilizce konuşma becerilerinin geliştiğini vurgulamışlardır.

\section{1.3 Öğretmen Desteği}

$\mathrm{Bu}$ tema, DynEd yazılımı ile etkili bir şekilde İngilizce öğrenmek için öğrencilerin yazılımı kullanmalarının dışında öğretmenin oynadığı rol ile ilgili öğrenci görüşlerinin yer aldığı ana temadır. 
Öğretmen desteğine örnek olarak; öğretmenin öğrenciler ile yapmış olduğu sınıf içi etkinlikler ve öğrencilerin DynEd yazılımının kullanımı ile ilgili sorunları için gerektiğinde öğretmelerine başvurabilmeleri verilebilir. Bu temaya ait alt tema bulunmamaktadır.

DynEd yazılımını kullanarak etkili bir şekilde İngilizce öğrenmede bir öğretmenin rehberlik etmesinin önemli ve faydalı olduğu ile ilgili toplam 87 çalışma grubu öğrencisinden 42 öğrenci (\%48) olumlu görüş belirtmiştir. Bu konuda sadece bir öğrenci kararsız ve bir öğrenci de olumsuz görüşte bulunmuştur.

$\mathrm{Bu}$ tema ile ilgili görüş bildiren öğrenci yanıtlarından öne çıkanlar şu şekildedir: Emir, "Programın kullanımı için bir ögretmene ihtiyacımız var çünkü öğretmen olmazsa kimse düzenli olarak çalışmaz."; Gülşen "Evde bir yere kadar ögrrenebilirim ama bir süre sonra bir ögretmenin anlatımına ihtiyacım olabilir" demiş; Ahmet ise "Rehber bir ögretmen ve DynEd'in yardımıyla İngilizceyi daha iyi öğrenirim" diyerek yazılımın dışında öğretmenin yaptığı desteğin DynEd'i kullanmada ve İngilizce öğrenmede önemli ve gerekli olduğunu vurgulamaktadırlar. İsmail,
Dyned bir çay ama ona bir şeker lazım yani dyned sadece olursa öğrenme yavaş olur ama yanında bir birey veya öğretmen olursa daha hızlı ve güzel öğreniriz. DynEd daha hoşumuza gider şekerli çay gibi. Bilgisayar öğretmenimiz maille ya da konuşarak bize anlatıp öğretmesi bizim detayları öğrenmemizi ve güzel çabalamamızı böylece hızlı gelişmemizi sağladı.

ifadeleriyle DynEd'in bireysel olarak kullanılmasının dışında sınıf içinde öğrencilerle ve öğretmenle etkinlikler yapıldığı zaman DynEd'i daha etkili kullanacaklarını ve dolayısıyla İngilizce dil becerilerinin daha çok artacağını belirtmektedir.

\section{1.4 Tutum}

Bu tema, öğrencilerin DynEd'i sevmesi ya da sevmemesi, faydalı ya da faydasız bulması, olumlu ya da olumsuz bulması gibi DynEd ile ilgili genel olarak hâkim olan tutuma ait öğrenci görüşlerinin yer aldığı ana temadır. Tablo 4'te öğrencilerin DynEd'e karşı tutumlarına ait öğrenci görüşleri yer almaktadır.

Tablo 4: Tutum Ana Temasına Ait Öğrenci Görüşleri

\begin{tabular}{cccc}
\hline Ana Tema & Öğrenci Görüşü & $\mathrm{n}$ & $\%$ \\
\hline \multirow{4}{*}{ Tutum } & Olumlu & 45 & 66,2 \\
& Kararsız & 6 & 8,8 \\
& Olumsuz & 17 & 25,0 \\
& Toplam & 68 & 100,0 \\
\hline
\end{tabular}

Tablo 4'e göre çalışma grubunu oluşturan 87 öğrenciden 68'i bu tema ile ilgili görüş bildirmiştir. Tutum ana temasına ait görüş bildiren öğrencilerden 45 'i $(\% 66,2)$ DynEd'e karşı olumlu tutum oluşturan ifadelerde bulunurken 17 'si $(\% 25)$ olumsuz, 6's1 $(\% 8,8)$ ise kararsız tutum oluşturacak söylemde bulunmuşlardır.

$\mathrm{Bu}$ tema ile ilgili görüş bildiren öğrenci yanıtlarından öne çıkanlar şu şekildedir: Duygu, "Bundan sonra İngilizcemi geliştirmek için DynEd'e girmeye devam etmek istiyorum" şeklinde; Helin "DynEd programına devam etmek istiyorum. Çünkü Ingilizcemi daha çok ilerletmek istiyorum. Bu programı yapanlara ve bu programda görev alan herkese teşekkür ediyorum"; Aysun ise "DynEd ögrenciler için gerçekten çok faydalı ve yararlı bir program. 7.sınıfta da kullanmayı düşünüyorum. Iyi ki ögretmenimiz bize böyle bir program gösterdiği için çok mutluyum. DynEd'i kuran herkese teşekkür ediyorum." ifadeleriyle DynEd ile ilgili olumlu görüşlerini belirtmektedirler. Gamze "Bana 
içerikler hep aynı olduğu için DynEd sıkıcı geldi ve fazla girmedim" şeklinde ve Burçak "Bir zamandan sonra slkmaya başlıyor." diyerek DynEd ile ilgili olumsuz görüşlerini ifade etmektedirler.

\section{1.5 Motivasyon}

$\mathrm{Bu}$ ana temada öğrenciler, öğretmenlerinin DynEd'in kullanılmasını arttıracak ders içi ve dışında yaptığı motive edici etkinlikler ile ilgili görüşlerini bildirmektedirler. Bu temaya ait dört adet alt tema bulunmaktadır. Tablo 5'te öğrencilerin Ödül, Yıldız Verilmesi, İlerleme Gösterimi ve TV alt temalarına ait görüşleri frekans ve yüzde olarak betimlenmektedir.

Tablo 5: Motivasyon Ana Temasına Ait Öğrenci Görüşleri

\begin{tabular}{cccc}
\hline Alt Tema & Öğrenci Görüşü & $\mathrm{n}$ & $\%$ \\
\hline \multirow{2}{*}{ Ödül } & Olumlu & 24 & 57,1 \\
& Kararsız & 14 & 33,3 \\
& Olumsuz & 4 & 9,5 \\
\hline \multirow{2}{*}{ Yıldız Çıkarma } & Olumlu & 17 & 85 \\
& Kararsız & 1 & 5 \\
& Olumsuz & 2 & 10 \\
\hline \multirow{3}{*}{ İlerleme Gösterimi } & Olumlu & 5 & 50 \\
& Kararsız & 2 & 20 \\
& Olumsuz & 3 & 30 \\
\hline \multirow{2}{*}{ TV } & Olumlu & 7 & 100 \\
& Kararsız & 0 & 0 \\
\hline
\end{tabular}

Tablo 5'e göre dönem sonunda en çok DynEd'de ilerleyip başarılı olan öğrenciye ödül olarak Tablet Bilgisayarın verilmesi ile ilgili öğrencilerin 24'ü $(\% 57,1)$ ödülün DynEd kullanımını arttırıcı ve motive edici etkiye sahip olduğunu belirterek olumlu, 14'ü $(\% 33,3)$ kararsız, 4'ü $(\% 9,5)$ ise ödülün DynEd kullanımında olumsuz bir etkiye sahip olduğunu ifade etmișlerdir. Haftalık olarak her sınıfta DynEd'de yüzdelik olarak en çok ilerleyen ilk 3 öğrenciye yıldız çıkartma verilmesi ile ilgili yorum yapan öğrencilerin çoğu $(\% 85)$ yıldız çıkartma verilmesinin motive edici etkiye sahip olduğunu belirtmektedirler.

$\mathrm{Bu}$ temayla ilgili görüş bildiren öğrencilere ait kararsız görüşler değerlendirmeye alınmayıp olumsuz görüşler de olumlu görüş sayılarından çıkarıldığı zaman, en çok ödül (\%45) verilmesi; sonra yıldız çıkartma (\%34) verilmesi; sonra aylık olarak en çok DynEd'de ilerleyen öğrencilerin okul TV'sinde (\%16) gösterilmesi; en az ise öğretmenin öğrencilerin DynEd'deki ilerlemelerini sınıfta gösterimi (\%5) öğrenciler tarafından motive edici olarak bulunmaktadır.

$\mathrm{Bu}$ tema ile ilgili görüş bildiren öğrenci yanıtlarından öne çıkanlar şu şekildedir: Duygu, "Bilgisayar ögretmenimizin haftalık DynEd ilerleme durumumuzu göstermesi, haftalı olarak yıldız ve aylık olarak da TV'de yayın yapması DynEd'e girmek için iyi motivasyon oldu. Ödül olması DynEd'e girişimde değişiklik yarattı." diyerek ödül, y1ldız, TV ve DynEd'de ilerlemenin gösterilmesine vurgu yapmaktadır. Gamze, "Ylldız almak benim motivasyonumu olumlu bir şekilde artırdı ama aramızda bir rekabet durumu oluşturduğu için aramızda kavgalar oluşabilirdi. Ödül DynEd'e girişimde bir etki yaratmadı ben DynEd'e ögrenme amactyla girdim." ifadeleriyle olumlu 
ve olumsuz görüşlerini bildirmiştir. Gülşen, "Sınıf içerisinde notlarımızın gözükmesi sizin etrafinızdakileri görüp daha fazla çalışmamıza yol açıyor. Kazanana ödül verilmesi bize hızlandırdl." ve Ahmet, "Başında ödül olduğu için ilgimi daha da çekti." şeklindeki ifadeleriyle ödülün önemine dikkat çekmişlerdir.

3.2 Harmanlanmış Öğretim Yöntemi Ortamında Öğrencilerin DynEd Yazılımının Etkileşim Butonlarını Kullanım Sıklıkları ve DynEd'de Geçirdikleri Süreler?

Tablo 6 öğrencilerin DynEd kullanımlarına ait betimsel istatistiklerini göstermektedir.

Tablo 6: Öğrencilerin DynEd Kullanımlarına Ait Betimsel İstatistikler

\begin{tabular}{ccccc}
\hline & $\bar{X}$ & S & Mak & Min \\
\hline Süre & $00: 07: 19$ & $00: 10: 18$ & $00: 57: 56$ & $00: 00: 02$ \\
Tekrar & 260 & 593 & 4129 & 0 \\
Mikrofon & 194 & 403 & 2622 & 0 \\
Kulaklık & 193 & 416 & 2619 & 0 \\
Sözlük & 7 & 27 & 235 & 0 \\
ABC & 10 & 31 & 228 & 0 \\
Çeviri & 15 & 52 & 370 & 0 \\
\hline
\end{tabular}

Not. DynEd'de geçirilen süre: Gün: Saat: Dakika cinsinden verilmiştir.

Tablo 6'ya göre öğrenciler; ortalama 7 saat 19 dakika süresince DynEd yazılımını kullanmışlar, en çok kullanan öğrenci ise 57 saat 56 dakika boyunca DynEd kullanmıştır. Kullanım süresine ait standart sapma ise 10 saat 18 dakikadır. Yazılım içinde öğrenciler duyduklarını tekrar dinlemek için tekrar butonunu ortalama 260 defa kullanmışlar; en çok kullanan öğrenci ise 4129 defa tekrar butonunu kullanmıştır. Konuşma ve telaffuz pratiği için öğrenciler mikrofon butonunu kullanarak ortalama 194 defa ses kaydı yapmışlar ve yaptıkları ses kaydını kulaklık butonu ile ortalama 193 defa dinlemişlerdir. Mikrofonla en çok 2622 defa ses kaydı yapılırken yapılan ses kaydı en çok 2619 defa dinlenmiştir. Yazılım içindeki sözlük özelliği kullanım sayısı, ABC butonu ile İngilizce alt yazı ve Çeviri butonu ile Türkçe dilinde alt yazı gösterim sayısı ortalamaları ise sırasıyla 7,10 ve 15 'tir.

Genel olarak öğrencilerin DynEd'in en çok tekrar butonunu kullandıkları görülmüştür. Ardından ise daha az sayıda ve neredeyse aynı sayıda mikrofon ve kulaklık özelliklerini kullandıkları görülmüsşürr. Mikrofon ve kulaklık kullanım sayısından çok daha az sayıda İngilizce ve Türkçe alt yazı kullandıkları belirlenmiştir. Tüm butonlar kıyaslanınca ise en az sayıda sözlük özelliğini kullandıkları belirlenmiştir.

\subsection{Harmanlanmış Öğretim Yöntemi Ortamında Öğrencilerin DynEd Düzey Belirleme} Sınav Başarıları

Tablo 7 ve 8 'de sirayla öğretim süreci öncesi ve sonrası uygulanan öğrencilerin Düzey Belirleme Sınavından elde ettikleri Puan ve Düzey bazında elde ettikleri sonuçlara ait betimsel veriler görülmektedir. 
Tablo 7: Öğretim Süreci Öncesi Uygulanan Düzey Belirleme Sınavı Analizi

\begin{tabular}{|c|c|c|c|c|c|c|c|}
\hline \multicolumn{4}{|c|}{ Puan } & \multicolumn{4}{|c|}{ Düzey } \\
\hline$\overline{\mathrm{X}}$ & $\mathrm{S}$ & Mak & Min & $\overline{\mathrm{X}}$ & $\mathrm{S}$ & Mak & Min \\
\hline 22 & 14 & 60 & 0 & 0,05 & 0,09 & 0,20 & 0,00 \\
\hline \multicolumn{8}{|c|}{ Tablo 8: Öğretim Süreci Sonrası Uygulanan Düzey Belirleme Sınavı Analizi } \\
\hline \multicolumn{4}{|c|}{ Puan } & \multicolumn{4}{|c|}{ Düzey } \\
\hline $\bar{X}$ & $\mathrm{~S}$ & Mak & Min & $\bar{X}$ & $\mathrm{~S}$ & Mak & Min \\
\hline 30 & 24 & 116 & 0 & 0,10 & 0,16 & 0,70 & 0,00 \\
\hline
\end{tabular}

Tablo 7'ye göre öğrenciler öğretim öncesi yapılan Düzey Belirleme Sınavından puan bazında ortalama 22 puan almışlar; 14 puanlık standart sapma görülmüş; en yüksek alan öğrenci ise 60 puan almıştır. Öğrenciler; düzey bazında ise ortalama 0,05 alırken en yüksek alan öğrenci 0,2 almıştır.

Tablo 8'e göre ise öğrenciler 3 aylık öğretim yöntemi sonrası yapılan Düzey Belirleme Sınavından puan bazında ortalama 30 puan almışlar; 24 puanlık standart sapma görülmüş; en yüksek alan öğrenci ise 116 puan almıştır. Öğrenciler; düzey bazında ise ortalama 0,10 alırken en yüksek alan öğrenci 0,7 almıştır. Tablo 7 ve 8 'deki sonuçlara göre harmanlanmış öğretim yöntemi ile uygulanan eğitim sürecinin sonunda öğrencilerde ortalama 8 puanlık bir artış olurken düzey bazında ise 0,05 düzeyinde bir artış olmuştur.

\section{Tartışma ve Öneriler}

Bilgisayar destekli İngilizce öğretim yazılımı olan DynEd'in harmanlanmış öğretim yöntemi ile uygulanmasına ilişkin öğrenci görüşlerinin, öğrencilerin DynEd kullanım durumlarının ve İngilizce akademik başarılarının araştırıldığı bu çalışmada elde edilen bulgular bu başlık altında tartışılmaktadır.

Çalışmanın birinci araştırma sorusu ile ilgili olarak öğrencilerin DynEd yazılımının harmanlanmış öğretim yöntemi ile birlikte kullanılmasına ilişkin görüşlerinin, genel anlamda olumlu olduğu sonucuna ulaşılmıştır. Açık uçlu anket sorularından elde edilen bulgulara göre görüş bildiren öğrencilerin önemli bir kısmının $(\% 66,2)$ DynEd yazılımına karşı tutumlarının olumlu olduğu görülmektedir. Bu durum alanyazındaki DynEd kullanımına ilişkin genel görüşlerin incelendiği çalışmalarla da örtüşmektedir (Baş, 2010; Ellsworth, 2015; Inal \& Korkmaz, 2019; Kim vd., 2014; Meri, 2012; Özek \& Pektaş, 2016; Tresnawati, 2011; Ucur, 2010). DynEd'in İngilizce akademik başarısına yaptığı katkı çerçevesinde öğrenciler sayıca en çoktan en aza konuşma becerileri, okuma, dinleme ve en az yazma becerileri açısından DynEd'i faydalı bulmuşlardır. Bu bulgular diğer araştırma sonuçları ile örtüşmektedir (Bahri, 2016; Bingham \& Larson, 2006; Brown vd., 2008; Çakmak, 2012; Ellsworth, 2015; Huang \& Wu, 2013; Sarıcaoğlu, 2010; Uras, 2018; Yiğit, 2010; 2012). Öğrencilerin yarısına yakını (\%48) DynEd ile İngilizce öğrenmede öğretmen desteğinin ve rehberliğinin önemli, faydalı ve gerekli olduğunu belirtmiştir. Bu durum DynEd'in harmanlanmış öğrenme desteği ile uygulanmasının önemini ortaya koymaktadır. Elde edilen bu sonucu destekler bir şekilde Ellsworth'ün (2015) çalışmasında öğretmen ve öğrenciler; DynEd eğitim sisteminin etkili ve verimli kullanılabilmesi için öğretmenin harmanlanmış öğretim kapsamında yaptığı sınıf içi etkinliklerin çok faydalı olduğunu ve öğretmenin önemli bir motivasyon kaynağı olduğunu ileri sürmüşlerdir. Alanyazında yapılan diğer araştırmalar da bu çalışmadakine benzer bir şekilde DynEd'in etkili ve verimli kullanılabilmesi için öğretmen desteğinin önemli ve faydalı olduğunu savunmaktadırlar (Brown vd., 2008; Huang \& Wu, 2013; Gobel, 2008; Kagaoan vd., 2012; Meri, 2012; Özgan \& Yiğit, 2011; Uras, 2018). Bir BDDÖ yazılımı olan DynEd'in öğrenciler tarafından kullanımının artması için öğretmenin yapacağı sınıf içi ve motivasyon etkinliklerinin önemli role sahip olduğu DynEd kılavuzu (DynEd International Inc., 2013; 2017) ve Knowles (2004) tarafindan da belirtilmektedir. Kim ve diğerleri (2012) ve Benson $(2001,2006)$ BDDÖ yazılımlarının etkili ve verimli bir şekilde kullanılması için motivasyonun kilit bir role sahip olduğunu ileri sürmektedirler. 
Ayrıca Ellsworth, (2015) yaptığı araştırmasına göre motivasyonun DynEd yazılımının etkin kullanılması için çok önemli ve gerekli olduğunu ifade etmektedir. Alanyazından elde edilen bu sonuçlar doğrultusunda bu çalışmada da öğrencilerin DynEd yazılımını verimli bir şekilde daha fazla kullanarak İngilizce becerilerinin artması için motivasyon etkinlikleri yapılmıştır. Öğrenciler; yapılan bu motivasyon etkinlikleri içerisinden DynEd'i doğru ve etkili bir şekilde kullanıp en fazla ilerleyenlere ödül $(\% 45)$ verilecek olmasını diğerlerine göre sayıca daha fazla olumlu ve etkili bulmuşlardır. Ödülden sonra en çok haftalık olarak DynEd'de en fazla ilerleyenlere yıldız çıkartma (\%34) verilmesini etkili bulmuşlardır. Bunların dışında daha az sayıda DynEd'de başarılı öğrencilerin okulun TV (\%16) ekranında yayınlanması ve en az sayıda DynEd yazılımında öğrencilerin ilerleme oranlarının sınıf içinde öğretmenleri tarafından gösterimi (\%5) öğrenciler tarafindan motivasyonu arttırıcı etkinlik olarak görülmüştür.

Çalışmanın ikinci araştırma sorusunda yer alan DynEd'i kullanım düzeyleriyle ilgili olarak öğrencilerin DynEd yazılımı arayüzündeki etkileşim butonları içinde yazılımı kullanırken duyduklarını tekrar dinlemek için kullandıkları tekrar butonunu ortalama olarak en fazla kullandıkları tespit edilmiştir (Tekrar: 260). Ses kaydı için kullanılan mikrofon ve kulaklık butonu kullanım sayıları ise ortalama olarak tekrardan daha az birbirine yakın oranda kullanılmıştır (Mikrofon:194, Kulaklık:193). Diğer Türkçe ve İngilizce altyazı butonları ile sözlük özelliği ise çok az kullanılmıştır (Türkçe Altyazı: 15, İngilizce Altyazı:10, Sözlük:7). Öğrencilerin DynEd'in etkileşim butonlarını kullanmada tekrarı en fazla, mikrofon ve kulaklığı ise birbirine benzer ve daha az sayıda kullanmaları, İngilizce ve Türkçe alt yazı butonlarını ise daha da az kullanmaları DynEd k1lavuzundaki önerilen kullanım şekli ile paralellik göstermektedir (DynEd International Inc., 2013). Tower (2000) ile Hegelheimer ve Tower'in (2004) yaptıkları çalışmalarda da bu çalışmadaki gibi DynEd'i etkili ve doğru kullanan öğrenciler tekrarı en çok, ses kaydı için mikrofon ve kulaklığı daha az ve birbirine benzer sayıda kullanmışlar, alt yazıyı ise az kullanmışlardır. Ayrıca Knowles (2004) yazılımın etkili kullanılması için etkileşim butonlarının kullanım şeklinin bu şekilde olması gerektiğini ileri sürmüştür. Çalışmada yazılım içindeki etkileşim butonlarının doğru ve birbirine göre istenilen oranda kullanılması, DynEd'in harmanlanmış öğretim yöntemiyle kullanılmasının bir sonucu olduğunu göstermektedir (DynEd International, Inc., 2009). DynEd yazılımındaki sözlük özelliğine; yazılım arayüzünde seçenekler düğmesine, ardından terimler sözlüğü düğmesine tıklanması ve kaydırarak istenilen sözcüğün bulunması yolu ile ulaşılır. Yazılımda en az sözlük özelliğinin kullanılmasının sebebi; bu özelliğin açıklandığı gibi yazılım arayüzünde doğrudan tıklanarak ulaşılamaması ve her kelimenin sözlük içinde bulunmamasından kaynaklandığı düşünülmektedir. Ulaşılan bu sonuçlar Hegelheimer ve Tower (2004), Gobel'in (2008) yaptıkları çalışmalarla örtüşmektedir. Onlar da çalışmalarında sözlük kullanım özelliğinin öğrenciler tarafından az kullanılmış olması, yazılım arayüzünden direkt bağlantı olmamasından kaynaklandığı sonucuna ulaşmışlardır. Kullanım düzeyleriyle ilgili genel bilgi vermesi açısından, öğrencilerin üç aylık süre boyunca DynEd'i kullanma süreleri ortalamasının 7 saat 19 dakika olduğu görülmüştür. Ancak DynEd yazılımının kullanım klavuzuna göre ise bu sürenin haftalık ortalama 2 saat, 12 haftada toplam 24 saat olmas1 gerekmektedir (DynEd International Inc., 2004; 2008; 2013). Bu da tüm çabalara rağmen öğrencilerin DynEd'i yeterli düzeyde kullanmadıklarını ortaya koymaktadır.

Yine çalışmanın ikinci araştırma sorusunda yer alan öğrencilerin DynEd'i kullanım şekilleriyle ilgili görüşleri açısından da önemli sonuçlar elde edilmiştir. İlk olarak DynEd programının özellikleri açısından öğrenciler; sayıca en çoktan en aza doğru sırasıyla ses kaydı ile kendi seslerini kaydedebilmeleri, duyduklarını tekrar dinleyebilmeleri, alt yazı ve sanal öğretmen özellikleri yönünden DynEd'i faydalı bulmuşlardır. Bunun yanında olumsuz görüşler bağlamında öğrencilerinden bazıları; DynEd programında ünite ilerleme hızının yavaş olduğunu ve DynEd'e ait beceri sınavlarının açılması için ünite tamamlama oranlarının \%80 olmasının gerekmediğini belirtmişlerdir. Gobel'in (2008) yapmış olduğu çalışmada da bu çalışmadaki sonuçlara paralel şekilde yazılıma ait sınavların geç açılması ve ilerlemenin yavaş olması ile ilgili öğrenci 
görüşlerinden bahsedilmiştir. Ayrıca öğrencilerden bazılarının bu yazılımın daha ilgi çekici ve eğlenceli bir şekilde tasarlanması yönünde talepleri olmuştur. Uras'ın (2018) yapmış olduğu çalışmasında da yazılımla ilgili benzer şekilde taleplerin olduğu olumsuz öğrenci görüşleri olmuştur.

Çalışmanın üçüncü araştırma sorusuyla ilgili bulgular incelendiğinde, düzey belirleme sınavı açısından öğrencilerin, ortalama olarak araştırma öncesi yapılan sınavda puan bazında 22, düzey bazında 0,05 ; araştırma sonrasında yapılan sınavda puan bazında 30 , düzey bazında ise 0,10 elde ettiği görülmüştür. Bu verilere göre öğrenciler araştırma sonrasında öncesine göre ortalama olarak daha başarılı olmuşlardır. Ortaya çıkan bu sonuç alanyazından elde edilen çalışma sonuçlarıyla desteklenmektedir (Bahri, 2016; Bingham \& Larson, 2006; Brown vd., 2008; Huang \& Wu, 2013; Inal \& Korkmaz, 2019; Kagaoan vd., 2012; Kim vd., 2014; Tresnawati, 2011; Uras, 2018). Öte yandan yapılan bu Düzey Belirleme Sınavlarına göre öğrenciler; ortalama olarak araştırma sonrasında araştırma öncesine göre düzey bazında 0,05 ve puan bazında ise 8 puan daha başarılı olsalar da DynEd kılavuzuna göre elde edilen bu başarı farkının anlamlı bir seviyede olmadığı görülmektedir. DynEd yazılımı kılavuzuna göre ise Düzey Belirleme Sınavında öğrencide anlamlı bir ilerleme olması düzey bazında en az 0,25 oranında bir artışın olması gerekmektedir (DynEd International Inc., 2004; 2008; 2013; 2017). DynEd kullanımı ve sınav başarısındaki bu durum öğrencilerin: (a) Özellikle DynEd'deki başarıları ile ilgili okul derslerini etkileyecek karne notu almamalarından; (b) harmanlanmış öğretim kapsamında yapılan sınıf içi etkinlikler için sınıfta çok fazla süre ayrılamamasından kaynaklandığı düşünülmektedir. Benzer sonucu bulan Kim ve diğerleri (2014) de öğrencilerin not almamasından dolayı DynEd kullanımının ve başarısının çok fazla olmadığını belirtmişlerdir.

Çalışmanın bu sonuçlarına dayanarak ülkemizde devlet okullarında DynEd yazılımının daha etkili ve verimli uygulanabilmesi için Millî Eğitim Bakanlığı ve İngilizce öğretmenlerine aşağıdaki önerilerde bulunulabilir:

- DynEd'in etkili uygulanmasına yönelik bilgilerin olduğu, iyi örneklerin paylaşıldığı ve diğer paylaşımların yapıldığı bir internet sitesi kurulabilir ya da www.eba.gov.tr sitesinde DynEd için özel bir alan açılabilir. Bu şekilde tüm öğretmen ve öğrencilere yönelik bilgilendirici bir platform oluşturularak DynEd'in kullanımı ile ilgili motive edici bir etki sağlanabilir.

- Okullarda işlenen Seçmeli İngilizce derslerine alternatif olarak Seçmeli DynEd Dersi eklenebilir. Böylece DynEd sisteminin önerdiği harmanlanmış öğrenme ortamı oluşturulup İngilizce eğitimi açısından en üst düzeyde verim elde edilebilir.

Böylece öğretmenler haftalık iki derslik seçmeli İngilizce derslerinde tamamen DynEd müfredatını uygulayarak derslerini işleyebilirler. Öğrencilerin okulda DynEd'i her hafta en az bir ders kullanacakları yeteri kadar donanımlı bir BT laboratuvarı olmadığını varsayarak seçmeli dersi seçen öğrencilerin evlerinde bir bilgisayar ya da tableti olmalıdır. Böylece öğrenci evinde DynEd'i kullanabilmeli ve işlenen üniteleri çalışabilmelidir. Okulda ise öğretmen rehberliğinde DynEd'in Kayıt Yöneticisinde bulunan sınıf içi etkinlikler (Extension Activities) yapılabilir, etkileşimli tahtalar kullanılarak sınıf içi etkinliklerin yapılmasında DynEd yazılımı kullanılabilir. Bunun dışında sınıf içi etkinlikler modülünde bulunan İngilizce çalışma kağıtları ödev verilip derste öğrencilerle birlikte yapılabilir. Öğrencilerin okulda DynEd kullanabilme imkanları varsa iki ders saatinin birinde öğrenciler DynEd kullanıp diğerinde sınıf içi etkinlikler yapılabilir. Seçmeli İngilizce dersinde yapılacak sınavlar için DynEd'in içinde bulunan beceri sınavları (Mastery Tests) kullanılabilir. Bu sınavların öğretmen tarafindan Kayıt Yöneticisinden açılarak öğrenciler tarafından imkân varsa okulda; yoksa belli zaman aralıkları belirlenip evde yapılması sağlanabilir. Bunun dışında okulda Kayıt Yöneticisi kullanılarak öğrencilerin ilerlemeleri kontrol edilip hatalı kullanımlar konusunda öğrenciler bilgilendirilebilir. Ayrıca yazılım içinde ünite ilerlemesi ve performansı iyi olan öğrencilere yıldız çıkartma ve benzeri ödüller verilerek DynEd'in etkin bir şekilde kullanılması yönünde motive edici etkinlikler yapılabilir. 


\section{Kaynakça}

Bahri, N. (2016). Investigating the impact of blended learning on learning English. ECEL 2016Proceedings of the 15th European Conference on e-Learning.

Baş, G. (2010). Evaluation of DynED courses used in elementary schools from the views of teachers in Turkey. Journal of Language and Linguistic Studies, 6(1), 14-39.

Baş, G., \& Kuzucu, O. (2009). Effects of CALL method and Dyned language programme on students' schievement levels and attitudes towards the lesson in English classes. International Journal of Instructional Technology and Distance Learning, 31-48.

Baz, F. (2010). Bilgisayar destekli yabancı dil eğitim yazılımı olan DynEd programının ögretmen ve ögrenci görüşleri açısından değerlendirilmesi. (Yüksek lisans tezi). Çukurova Üniversitesi Sosyal Bilimler Enstitüsü, Adana. https://doi.org/10.9761/jasss2697

Baz, F., \& Tekdal, M. (2014). Evaluation of computer based foreign language learning software by teachers and students. TOJET: The Turkish Online Journal of Educational Technology, 13(2), 71-78.

Benson, P. (2001). Teaching and researching autonomy in language learning. Harlow, England: Pearson Education, Ltd.

Benson, P. (2006). Autonomy in language teaching and learning. Language Teaching, 21-40.

Berkant, H. G., \& Derer, Ö. K. (2016). Teachers' opinions regarding the effectiveness of DynEd language education system in english language teaching. The Turkish Online Journal of Educational Technology, 16(December Issue for INTE 2016), 611-620.

Bingham, S., \& Larson, E. (2006). Using CALL as the major element of study for a university English class in Japan. The Jalt Call Journal, 2(3), 39-52. https://doi.org/10.29140/jaltcall.v2n3.31

Brown, I., Campbell, A., \& Weatherford, Y. (2008). Using DynEd and ALC with low-level university freshmen. JALT CALL Journal, 4(3), 37-53. https://doi.org/10.29140/jaltcall.v4n3.68

Büyüköztürk, Ş., Kılıç Çakmak, E., Erkan Akgün, Ö., Karadeniz, Ş., \& Demirel, F. (2016). Bilimsel araştırma yöntemleri. Pegem Akademi. https://doi.org/10.14527/9789944919289

Coşkun, E. (2013). Bilgisayar destekli eğitimde, DynEd programının ilköğretim İngilizce dersini desteklemesi hakkındaki ögretmen görüşleri (Kırşehir ili örneği). (Yüksek lisans tezi). Ahi Evran Üniversitesi Sosyal Bilimler Enstitüsü, Kırşehir. https://doi.org/10.31592/aeusbed.666691

Çakmak, B. (2012). Appraising DynEd: a study into the teaching of language skills and technical features. (Master's thesis). Istanbul University Division of English Language Teaching, İstanbul.

Decena, R. A., Basilisco, J., \& Juanillo, R. F. (2015). Fractal analysis on the performance of students in English language using computer-aided language learning and DynEd software. NMSCST Research Journal, 3(1), 203-215.

Döngel, A. (2011). Dyned; Bilgisayar destekli İngilizce programının ilköğretim İngilizce dersi öğretim programlarına uygunluğu yönünden içerik analizi (5. sınıf örneği). 2nd International 
Conference on New Trends in Education and Their Implications, 27-29. https://doi.org/10.14527/9786052412480.12

DynEd International Inc. (2004). First English: instructor's guide version 1.0. Burlingame, CA.

DynEd International Inc. (2008). Records Manager guide version 2.5.1. Burlingame, CA.

DynEd International, Inc. (2009). Teaching English: A brain based approach instructor's guide. Burlingame, CA.

DynEd International Inc. (2013). Teacher's guide for DynEd's Placement Tests. Burlingame, CA.

DynEd International, Inc. (2017). Company documentation. Burlingame, CA.

Ellsworth, G. (2015). Teacher and student perceptions of DynEd Multimedia Courseware: an evaluation of CALL in an American Technical College. (Master's thesis). School of Education Student Capstone Theses and Dissertations, Saint Paul.

Gobel, P. (2008). Student off-task behavior and motivation in the CALL classroom. International Journal of Pedagogies and Learning, 4(4), 4-18. https://doi.org/10.5172/ijpl.4.4.4

Hegelheimer, V., \& Tower, D. (2004). Using CALL in the classroom: Analyzing student interactions in an authentic classroom. System 32, 185-205. https://doi.org/10.1016/j.system.2003.11.007

Huang, J., \& Wu, B. (2013). A research on the effectiveness of DynEd computer-assisted English language learning-taking Ningbo Polytechnic as an example. Pacific Rim Objective Measurement Symposium (PROMS) 2012 Conference Proceeding, 155-177. https://doi.org/10.1007/978-3-642-37592-7_12

Inal, M., \& Korkmaz, Ö. (2019). The effect of web based blended learning on students academic achievement and attitudes towards English course. Springer US. https://doi.org/10.1007/s10639-019-09890-7

Kagaoan, A., Muya, G., Tibayan, C., \& Tenorio, N. (2012). The effect of dynamic education intervention program in the fundamentals of English course. Lyceum of the PhilippinesLaguna Research Journal, 2(1).

Kim, J., Cho, Y., \& Lee, Y. (2014). Exploring the effects of multimedia-based self-directed English speaking practice. Multimedia-Assisted Language Learning, 17(4), 61-87. https://doi.org/10.15702/mall.2014.17.4.61

Knowles, L. (2004). The Evolution of CALL. Journal of Communication \& Education.

Krippendorff, K. (2004). Content analysis: an introduction to its methodology. Thousand Oaks, CA: Saga.

Meri, S. (2012). Autonomous computer-assisted language learning: Turkish primary school students' perceptions of DynEd software. International Conference "ICT For Language Learning.

Özek, M. B., \& Pektaş, M. (2016). Ortaokul öğrencilerinin İngilizce öğretiminde DynEd programını kullanmaya ilişkin tutum ve motivasyonları. Öğretim Teknolojileri \& Öğretmen Ĕgitimi Dergisi, 5(1).

Özgan, H., \& Yiğit, C. (2011). Teachers' opinions about how to use DynEd in an effective way. eJournal of New World Sciences Academy, 6(1), 87-95.

Phakiti, A. (2014). Experimental research methods in language learning. London: Bloomsbury. 
Sarıcaoğlu, A. (2010). The use of the international computer-assisted language learning program "Dynamic English" (DynEd) in primary schools in Turkey. (Master's thesis). Hacettepe University Department of Foreign Language Teaching, Ankara.

Sim, J., \& Wright, C. (2005). The kappa statistic in reliability studies: use, interpretation, and sample size requirements. Physical therapy, 85(3), 257-268. https://doi.org/10.1093/ptj/85.3.257

Stevenson, A. (2010). Oxford Dictionary of English (3 ed.). Oxford: Oxford University Press.

Şahinkayası, H., \& Şahinkayası, Y. (2013). Deneysel araştırmalar ve öğretim teknolojileri. K. Çağıltay, \& Y. Göktaş içinde, Öğretim Teknolojilerinin Temelleri: Teoriler, Araştırmalar, Eğilimler. Ankara: Pegem Akademi.

Şengel, E., Oncu, S., \& Goktalay, S. (2011). How does a CALL software impact student learning: The DynEd case in Turkey. EdMedia: World Conference on Educational Media and Technology, 3208-3216.

Şengel, E., Öncü, S., \& Göktalay, Ş. (2012). Attitudes and motivation of English language teachers concerning the DynEd system in secondary schools. E-journal of New World Sciences Academy, 7(2), 516-525.

Şengel, E., Öncü, S., \& Göktalay, Ş. (2014). Achievement in language learning: effects of various computer assisted activities and computer literacy. Hacettepe University Journal of Education, 267-279.

Tower, D. (2000). A quantitative interaction analysis of an authentic CALL environment: New Dynamic English. (Master's thesis). Iowa State University, Ames. https://doi.org/10.31274/rtd-180814-5385

Tresnawati, F. (2011). The implementation of computer-assisted language learning (CALL) by using dynamic education (DynEd) program in improving english proficiency of vocational high school students. Bandung: Indonesian University of Education.

Uras, S. (2018). DynEd mobil yazılımının ortaöğretim öğrencilerinin İngilizce dersi akademik başarılarına etkisi. (Yüksek lisans tezi). Ege Üniversitesi Fen Bilimleri Enstitüsü, İzmir. https://doi.org/10.25092/baunfbed.428983

Yiğit, A. (2010). Teachers' attitudes towards the "DynEd" in primary education in Turkey: from the 4th to 8th grades. (Master's thesis). Karadeniz Teknik Üniversitesi Sosyal Bilimler Enstitüsü, Trabzon.

Yiğit, A. (2012). Evaluating the problems encountered in the DynEd implementation and implications for Elt. Journal Of Educational And Instructional Studies In The World, 2(4), 143-153.

Yıldırım, A., \& Şimşek, H. (2011). Sosyal Bilimlerde Nitel Araştırma Yöntemleri. Ankara: Seçkin. 